Agritech, 38 (2) 2018, 227-233

\title{
Teknologi Kolektor Surya Berlubang tanpa Kaca Transparan untuk Mengeringkan Daun Gaharu
}

\author{
Technology of Perporated Unglazed Solar Collector for Drying Gaharu Leaves \\ Irwin Bizzy*, Budi Santoso², Muhammad Zahri Kadir³ \\ 1,3Jurusan Teknik Mesin, Fakultas Teknik, Universitas Sriwijaya, Jl. Raya Palembang-Prabumulih Km. 32, Inderalaya, \\ Ogan Ilir 30662, Indonesia \\ 2Jurusan Teknologi Pertanian, Fakultas Pertanian, Universitas Sriwijaya, Jl. Raya Palembang-Prabumulih Km. 32, \\ Inderalaya, Ogan Ilir 30662, Indonesia \\ *Email: irwin@unsri.ac.id
}

Tanggal submisi: 18 November 2017; Tanggal penerimaan: 14 Mei 2018

\begin{abstract}
ABSTRAK
Teknologi kolektor surya berlubang ini merupakan salah satu solusi untuk dapat memanfaatkan energi terbarukan yang peluangnya sangat besar untuk dikembangkan di negara beriklim tropis seperti Indonesia. Teknologi ini dapat digunakan sebagai teknologi tepat guna untuk mengeringkan produk-produk pertanian. Tujuan penelitian ini adalah untuk menentukan laju penurunan kadar air daun gaharu. Dalam pengujian pengeringan ini digunakan kolektor surya berlubang bersayap empat. Evaluasi efisiensi pelat kolektor surya berlubang dilakukan di Wind Tunnel Laboratorium Fenomena Dasar, Jurusan Teknik Mesin, Universitas Sriwijaya. Dimensi dari pelat kolektor surya berlubang adalah 850 $\mathrm{mm} \times 300 \mathrm{~mm} \times 1,5 \mathrm{~mm}$, dengan jumlah lubang 1.018 buah yang berdiameter $2,5 \mathrm{~mm}$. Hasil penelitian menunjukkan bahwa laju pengeringan daun gaharu untuk mencapai kadar air 10\% dapat dihasilkan dalam 2-3 hari. Kondisi ini terjadi bila cuaca cerah, tidak hujan dan tidak berawan. Dalam kondisi lain, ketika matahari bersinar dengan radiasi matahari rata-rata yang mencapai permukaan lebih besar atau sama dengan $500 \mathrm{~W} / \mathrm{m}^{2}$. Pengujian efisiensi kolektor surya pelat alumunium berlubang dengan parameter kecepatan udara, menunjukkan bahwa pelat berwarna hitam menghasilkan performa yang lebih baik $(12,83 \%)$ dibandingkan dengan pelat tanpa warna $(6,36 \%)$.
\end{abstract}

Kata kunci: kolektor surya berlubang; pengeringan, daun gaharu

\section{ABSTRACT}

The perforated solar collector technology is a highly potential solution to take advantage of renewable energy in tropical countries such as Indonesia. This technology can be applied as a simple technology for drying of agricultural products. This study aims to determine the rate of the decreased moisture content of gaharu leafs. In this study, the perforated solar collector equipped with four ribs was used. The efficiency evaluation of perforated solar collector plate was conducted in Wind Tunnel-Rig, Basic phenomenon Laboratory of Mechanical Engineering Department, Sriwijaya University. The dimension of the plate is $850 \mathrm{~mm} \times 300 \mathrm{~mm} \times 1.5 \mathrm{~mm}$, which has 1018 holes with $2.5 \mathrm{~mm}$ in diameter. The results show that the drying rate for achieving the $10 \%$ moisture content of the gaharu leafs, can be reached in 2-3 days. This condition occurs when the weather is sunny, or not cloudy and rainy. In other condition, when the sunshine with an average solar irradiation on the surface is greater than or equal $500 \mathrm{~W} / \mathrm{m}^{2}$. The efficiency tests of the perforated aluminum plate solar collector using wind velocity as input parameter show that the blackened plate resulted in better performance $(12,83 \%)$ than the colorless one in $(6,36 \%)$.

Keywords: Air velocity; efficiency; solar perforated collector; solar radiation

\section{PENDAHULUAN}

Pengembangan penelitian kolektor surya dari tahun ke tahun berkembang dengan cepat, salah satu yang sering diteliti adalah kolektor surya berlubang tanpa kaca transparan. Kolektor surya berlubang telah diteliti antara lain untuk mengurangi beban pendingin gedung (Collins dkk., 2014), memakai simulasi computational fluid mechanics tanpa kecepatan angin (Arulanandam dkk., 1999), membandingkan penelitian eksprimen dan numerik (Badache dkk., 2013), dan telah diteliti unjuk kerja kolektor surya berlubang di Turki (Eryener dkk., 2016). Demikian pula, Croitoru dkk. (2016) telah 
meneliti kolektor surya berlubang untuk pemanasan awal udara ruangan sebuah gedung untuk menghasilkan kinerja yang tinggi. Semakin bertambah laju aliran udara melalui kolektor surya berlubang, semakin meningkat laju perpindahan kalornya.

Kolektor surya berlubang adalah sebuah pelat yang diberi lubang-lubang untuk mengurangi kerugian panas konveksi di atas permukaan pelat kolektor. Kolektor surya tipe ini dipakai dengan tujuan dapat mengurangi biaya pembuatannya dan lebih praktis dalam aplikasinya. Selama ini, kolektor surya masih berfokus pada penggunaan kaca transparan untuk menangkap radiasi matahari yang datang ke permukaan kolektor untuk memanaskan udara. Adapun kolektor tipe ini dimanfaatkan antara lain untuk pemanas udara ruangan dan mengeringkan produk-produk pertanian.

Menurut (Vijayavenkataraman dkk., 2012) , umumnya produk-produk pertanian, seperti kopi, tembakau, teh, buah-buahan, coklat, dan beras hanya membutuhkan energi dalam bentuk panas yang temperaturnya rendah untuk proses pengeringannya. Kadar air produk yang dikeringkan adalah salah satu unsur yang ingin dicapai dalam proses pengeringan produk-produk pertanian. Sebagai contoh, telah dilakukan pengujian terhadap cabe merah oleh (Banout dkk., 2011) dengan menggunakan tiga metode yaitu peralatan pengering surya tipe laluan ganda, model kabinet, dan dijemur langsung di udara terbuka di Vietnam. Hasil yang didapat berupa waktu pengeringan masing-masing perlakuan adalah 32 jam, 73 jam, dan 93 jam untuk mencapai kadar air 10\%.

Berbagai model peralatan pengering surya telah dibuat dan mengutamakan pemakaian bahan-bahan yang murah, seperti plastik transparan yang dilakukan di Bangladesh (Mohsin dkk., 2011) sebagai kolektor untuk menerima radiasi matahari yang memanaskan udara sebagai pemanas dan terbukti lebih hemat dan ramah lingkungan dibandingkan memakai bahan bakar berasal dari fosil, seperti minyak, batubara, dan gas. Sedangkan (Bagheri dkk., 2012) telah meneliti pengaruh pengaturan kecepatan fan untuk mengoptimasi energi dalam kolektor pengering surya. Hasil penelitiannya menunjukkan model simulasi yang telah dilakukan mampu memodelkan kecepatan kipas dan sistem kontrol yang dibuat mampu meningkatkan efisiensi pengering.

Peneliti Li dkk, (2013) telah meneliti kolektor surya berlubang tipe pelat datar dan bergelombang dengan variasi laju aliran serta menganalisis lapisan batas termal yang terjadi pada kedua pelat tersebut. Hasil penenlitiannya menunjukan pertambahan jarak pelat bertambah akan meningkatkan tebal lapisan batas termal. Tebal lapisan batas termal untuk tipe pelat bergelombang lebih baik dibandingkan pelat datar. Sementara itu, telah diteliti desain pemanas udara surya pelat berlubang oleh Bizzy (1996) yang meliputi diameter, jumlah, dan susunan lubang. Hasil penelitian menunjukkan efisiensi sesaat masing-masing kolektor bertambah dengan kenaikan kecepatan aliran udara dan desain terbaik diperoleh pada diameter 2,5 $\mathrm{mm}$ dan jumlah lubang 2256 buah dengan susunan staggered.
Demikian pula, telah dirancang sebuah peralatan pengering kapasitas $2 \mathrm{~kg}$ daun gaharu dengan kolektor surya berlubang mini bersayap empat memanfaatkan beda densitas udara atau perpindahan kalor konveksi bebas (Bizzy dkk., 2012). Daun gaharu dipilih sebagai objek produk yang dikeringkan dikarenakan memiliki kandungan antioksidan yang bermanfaat bagi tubuh manusia melalui proses pembuatan teh gaharu dari daun gaharu (Santoso dkk., 2012). Bila dimakan langsung daun gaharu akan terasa pahit dan tidak disukai sehingga perlu dijadikan teh gaharu dengan perlakuan khusus pada teknologi pengeringannya. Dari hasil penelitian diketahui bahwa antioksidan yang tinggi dihasilkan pada temperatur pengeringan rendah yaitu pada $38{ }^{\circ} \mathrm{C}$ dengan kelembaban relatif 47 s.d. $2 \%$. Pengujian terhadap keamanan teh gaharu yang dikeringkan telah dilakukan pula oleh (Kamaludin, 2012) dan disimpulkan bahwa teh gaharu aman untuk dikonsumsi manusia.

Adapun tujuan penelitian kolektor surya berlubang ini adalah untuk mengeringkan daun gaharu pada pembuatan teh gaharu dengan memanfaatkan sinar matahari dan melakukan pengujian terhadap pelat kolektor surya berlubang menggunakan terowongan angin atau wind tunnel untuk melihat pengaruh kecepatan udara di atas permukaan kolektor, pengaruh pelapis dan tanpa pelapis berwarna hitam pada pelat kolektor.

\section{METODE PENELITIAN}

\section{Bahan}

Bahan-bahan yang digunakan adalah pelat alumunium, kerangka besi, dan isolator. Sedangkan daun gaharu yang dipilih adalah pucuk daun gaharu yang masih muda dan segar dari kebun gaharu milik petani di Kecamatan Gandus Kota Palembang Provinsi Sumatera Selatan.

\section{Alat}

Alat-alat ukur yang digunakan adalah sebuah piranometer atau Solar Power Meter model SPM-1116SD buatan Taiwan atau pengukur radiasi matahari yang datang ke permukaan kolektor, alat pengukur temperatur dengan kawat termokopel tipe K, timbangan (Tipe ACS-ZE 21W, Zhongshan Camry Electronic Co. Ltd., China), lampu, dan alat ukur kecepatan aliran udara.

\section{Rancangan Penelitian}

Metode penelitian yang digunakan adalah pertama eksprimen di lapangan dengan merancang sebuah peralatan uji berupa kolektor surya berlubang dengan udara tarikan paksa oleh sebuah blower untuk mengeringkan daun gaharu. Skema pengujian ini ditunjukan pada Gambar 1. 


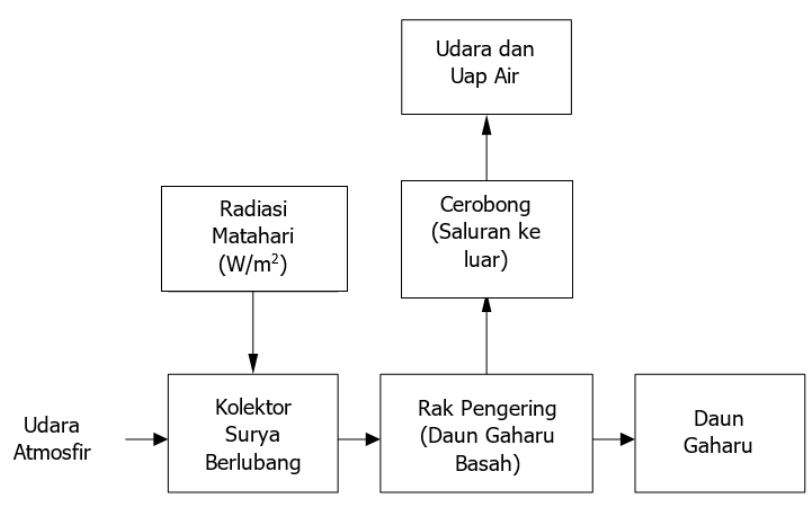

Gambar 1. Skema pengujian kolektor surya berlubang untuk mengeringkan daun gaharu

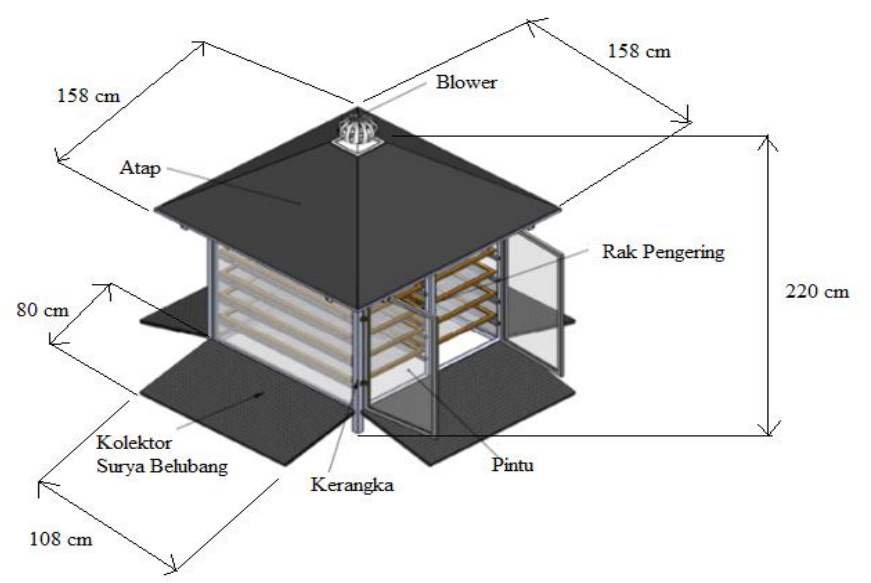

Gambar 2. Kolektor surya berlubang bersayap empat

Keempat sisi dinding dipasang pelat yang berbahan alumunium yang diberi cat warna hitam. Empat buah kolektor surya berlubang diletakkan pada keempat posisi memiliki sudut kemiringan $15^{\circ}$ dengan diberi lubang dan pelatnya dicat warna hitam (Gambar 2). Bahan pelat adalah alumunium berdimensi $1080 \mathrm{~mm} \times 800 \mathrm{~mm} \times 0,8$ $\mathrm{mm}$. Jarak antar lubang dan diameter lubang masingmasing adalah $15 \mathrm{~mm}$ dan 2,5 mm. Bagian ujung bawah keempat kolektor surya berlubang dipasang saluran untuk pembuangan air. Peralatan ukur intensitas matahari diletakkan di atas permukaan kolektor berlubang, sedangkan untuk mengukur kecepatan angin diletakkan di samping kolektor, dan pengukur temperatur di beberapa titik dalam ruang pengering.

Eksprimen juga dilakukan di laboratorium dengan cara menguji pelat kolektor surya berlubang dalam sebuah Wind Tunne/ berukuran $850 \mathrm{~mm} \times 300 \mathrm{~mm}$. Permukaan pelat kolektor yang diuji terdiri dari pelat kolektor yang permukaannya dicat warna hitam dan tanpa diberi warna. Sumber radiasi berasal dari sebuah sinar lampu. Posisi pelat kolektor dalam wind tunne/ sejajar dengan arah aliran udara (Gambar 3).

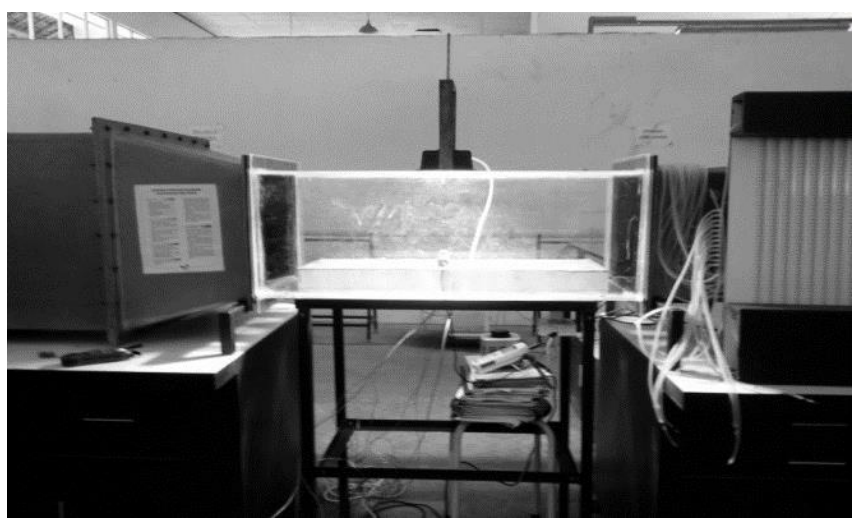

Gambar 3. Pengujian pelat kolektor surya berlubang dalam wind tunnel

\section{Cara Kerja}

\section{Kolektor surya berlubang}

Kolektor surya berlubang dirancang dengan 8 (delapan) rak untuk meletakkan daun gaharu dan 4 (empat) sayap yang diberi lubang-lubang kecil (Gambar 2). Seluruh permukaan kolektor diberi warna hitam untuk menyerap panas sebanyak mungkin dan diletakkan pada lapangan terbuka sehingga sinar matahari yang datang dapat diterima oleh kolektor secara penuh. Daun gaharu diletakkan pada rak pengering dan blower digerakkan oleh adanya beda temperatur, densitas udara dan hembusan angin dari luar.

Udara atmosfir masuk melalui lubang-lubang di permukaan kolektor, kerugian panas akibat perpindahan kalor konveksi dari permukaan ke udara atmosfir dapat diserap kembali ke ruang pengering akibat adanya beda densitas udara masuk dan ke luar kolektor. Selain itu, udara masuk dan keluar juga dibantu oleh isapan blower yang diletakkan di saluran cerobong atau pembuangan di kolektor.Udara yang ke luar melalui cerobong adalah udara basah (udara dan uap air). Uap air yang dikeluarkan merupakan penjumlahan uap air yang ada dalam udara atmosfir dan yang dikeluarkan dari daun gaharu akibat proses penguapan.

\section{Pengujian pelat kolektor di wind tunnel}

Adapun alasan dilakukan pengujian pelat kolektor surya berlubang di laboratorium menggunakan sebuah wind tunnel adalah untuk mengetahui pengaruh kecepatan udara di atas permukaan pelat kolektor (di lapangan kesulitan mengukur kecepatan angin di atas permukaan pelat kolektor yang selalu berubah-ubah setiap saat). Gambar 4 menunjukkan skema perpindahan kalor radiasi dan perpindahan kalor konveksi paksa di atas permukaan kolektor surya berlubang. 


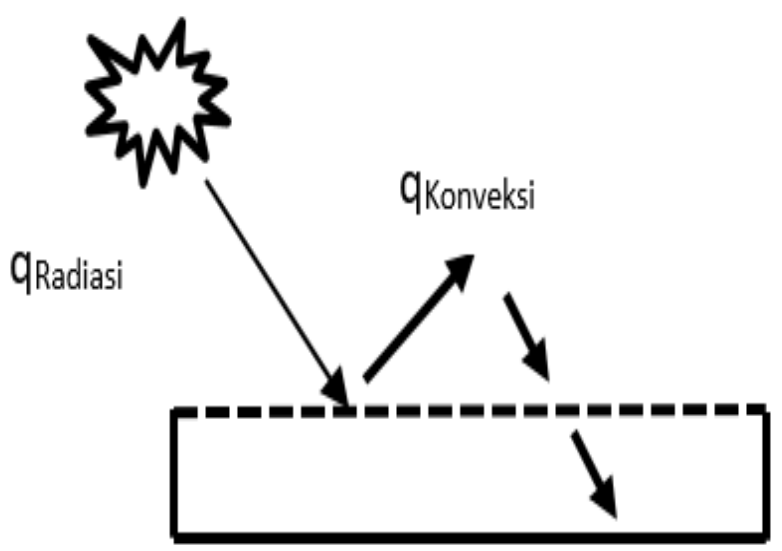

Gambar 4. Skema perpindahan kalor di kolektor surya berlubang

Radiasi yang datang ke permukaan kolektor surya berlubang akan diterima oleh permukaan kolektor baik melalui lubang secara langsung, melalui pelat dipantulkan ke udara atmosfir berupa perpindahan kalor konveksi atau kerugian kalor. Selanjutnya, lubang yang dibuat berfungsi menangkap kerugian perpindahan kalor konveksi udara ini melalui lubang-lubang dipermukaan kolektor dengan bantuan tarikan blower menuju ruang pengering.

Data pengujian pelat kolektor surya berlubang di dalam wind tunne/ disesuaikan dengan ukuran peralatan uji yang tersedia untuk waktu pengujian masing-masing perlakuan 30 menit dengan spesifikasi kolektor:

a. Diameter lubang kolektor surya berlubang $d_{o}=2,5$ $\mathrm{mm}$

b. Jumlah lubang, $\mathrm{n}=1.018$ buah dan jarak antar lubang $15 \mathrm{~mm}$

c. Ukuran pelat kolektor yang diuji $=850 \mathrm{~mm} \times 300 \mathrm{~mm}$

d. Tebal pelat kolektor, $t=0,5 \mathrm{~mm}$ berbahan alumunium.

e. Permukaan pelat kolektor diberi warna (hitam) dan tanpa diberi warna

f. Kecepatan udara di atas pelat kolektor dalam Wind Tunne/ atau Vudara divariasikan:

$V_{\text {udara }}=0 \mathrm{~m} / \mathrm{s} ; 0,5 \mathrm{~m} / \mathrm{s} ; 1,0 \mathrm{~m} / \mathrm{s} ; 2,0 \mathrm{~m} / \mathrm{s} ; 3 \mathrm{~m} / \mathrm{s} ; 5$ $\mathrm{m} / \mathrm{s}$.

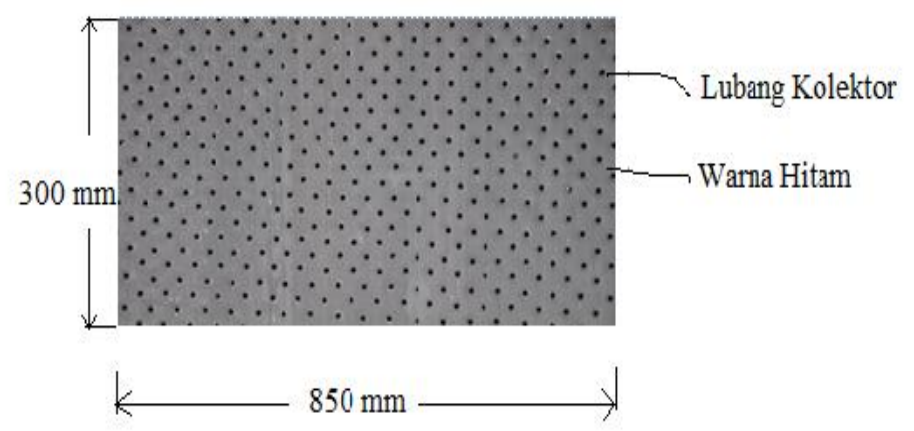

Gambar 5. Bentuk dan dimensi kolektor surya berlubang
Pelat kolektor surya berlubang diletakkan secara horizontal sejajar arah aliran udara di dalam wind tunnel dan disinari lampu sebesar 300 Watt sebagai pengganti sinar matahari. Penggunaan lampu dalam pengujian ini bertujuan menjaga radiasi yang datang ke permukaan pelat kolektor dalam besaran yang sama.

\section{HASIL DAN PEMBAHASAN}

Data radiasi matahari yang datang di permukaan kolektor surya berlubang di lapangan diambil berdasarkan standar ASHRAE 93-77 dan sebagai contoh radiasi matahari tanggal 03 Oktober 2013, 05 Oktober, dan 09 Oktober 2013 dari 09.00 s.d. 16.00 pada Gambar 6, Gambar 7, dan Gambar 8. Radiasi matahari yang datang permukaan kolektor sangat berfluktuasi per menit waktu pengambilan data. Berdasarkan standar, perhitungan efisiensi kolektor dipilih setiap 15 menit dengan radiasi yang datang ke permukaan kolektor ratarata di atas $500 \mathrm{Watt} / \mathrm{m}^{2}$.

Radiasi yang datang ke permukaan kolektor sangat berfluktuasi bergantung pada cuaca dan kecepatan angin di atas permukaan kolektor. Sebagai contoh, ditunjukan pada Gambar 4, Gambar 5, dan Gambar 6 dimana keadaan saat pengambilan data, keadaan cuaca panas tetapi sedikit berawan. Radiasi matahari yang diterima oleh permukaan kolektor menurun ketika sinar matahari dihalangi oleh awan. Pengujian pengeringan daun gaharu menggunakan kolektor surya berlubang seberat $5 \mathrm{~kg}$ basah, dimulai dari tanggal 03 Oktober 2013 sampai dengan 09 Oktober 2013, kecepatan angin rata-rata saat pengujian adalah $0,3 \div 0,5 \mathrm{~m} / \mathrm{s}$. Gambar 9 menunjukan data hasil pengurangan kadar air daun gaharu rata-rata dari 8 (delapan) rak (03 s.d. 09 Oktober 2013). Kadar air daun gaharu rata-rata dapat diturunkan mencapai $10 \%$ selama 2-3 hari apabila sinar matahari rata-rata lebih besar sama dengan $500 \mathrm{~W} / \mathrm{m}^{2}$. Sebagaimana, penurunan kadar air juga terjadi pada pengeringan buah pisang yang diteliti oleh Lingayat (2017). Kadar air buah pisang berkurang dengan bertambahnya waktu pengeringan. Peralatan pengering surya yang digunakannya adalah pelat penyerap panas tipe $\mathrm{V}$ bergelumbang.

Kadar air berat basah $\left(m_{b b}\right)$ daun gaharu dirumuskan pada Persamaan 1.

$$
m_{b b}=\frac{w_{1}}{w_{1}+w_{2}} \times 100 \%
$$

$\mathrm{w}_{1}=$ berat air dalam daun gaharu $(\mathrm{kg})$

$\mathrm{W}_{2}=$ berat daun gaharu kering $(\mathrm{kg})$

Kadar air berat kering ( $\left.m_{b k}\right)$ daun gaharu dirumuskan pada Persamaan 2.

$\mathrm{m}_{\mathrm{bb}}=\frac{\mathrm{w}_{1}}{\mathrm{w}_{2}} \times 100 \%$ 


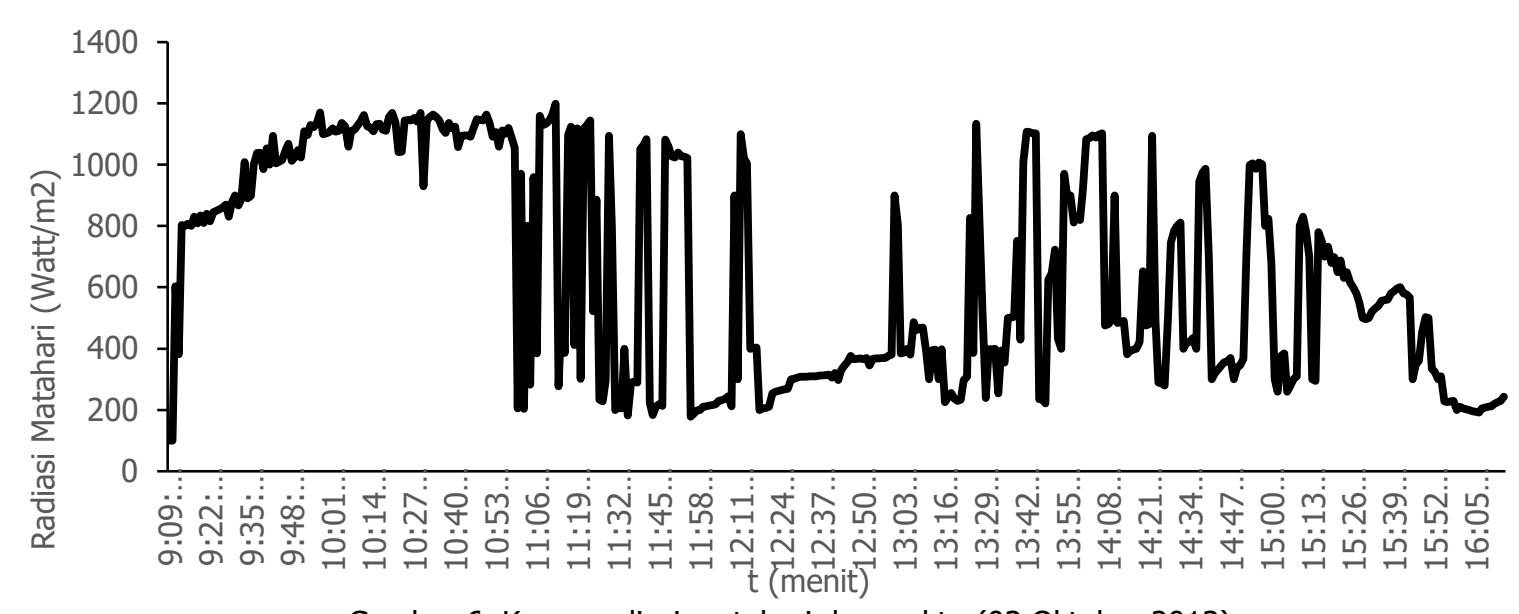

Gambar 6. Kurva radiasi matahari dan waktu (03 Oktober 2013)

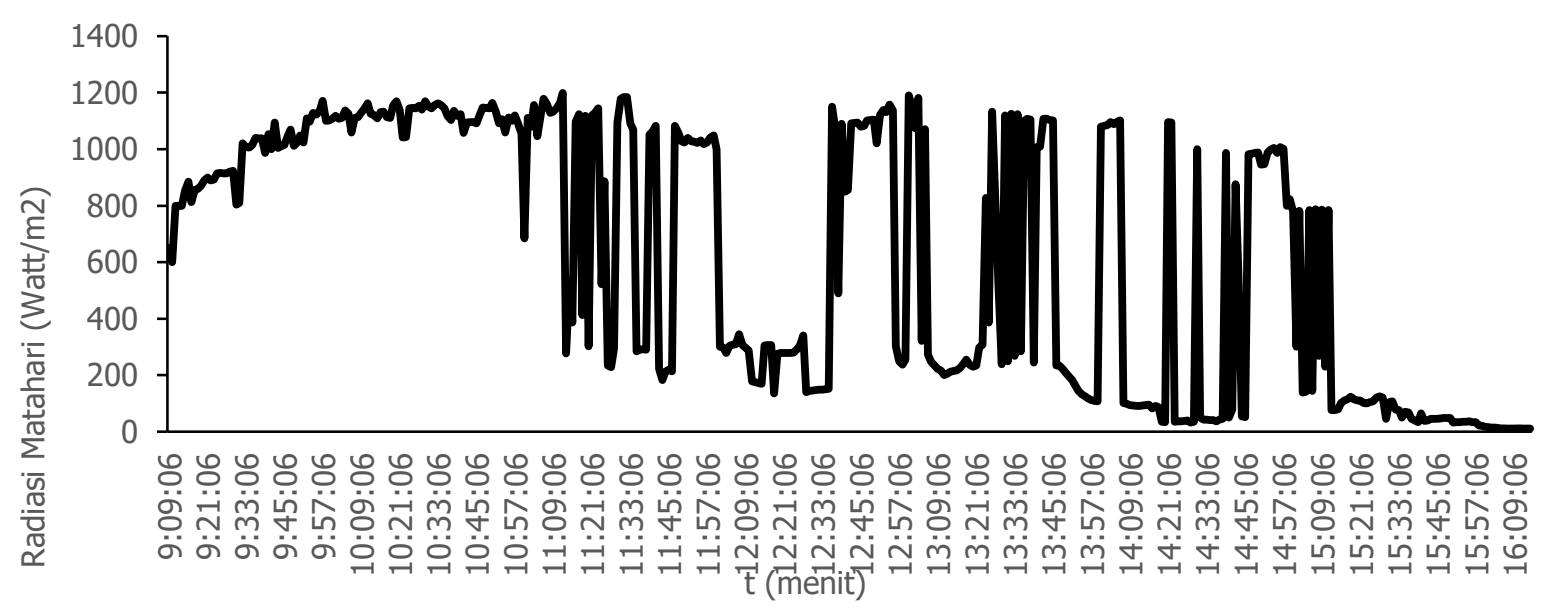

Gambar 7. Kurva radiasi matahari dan waktu (05 Oktober 2013)

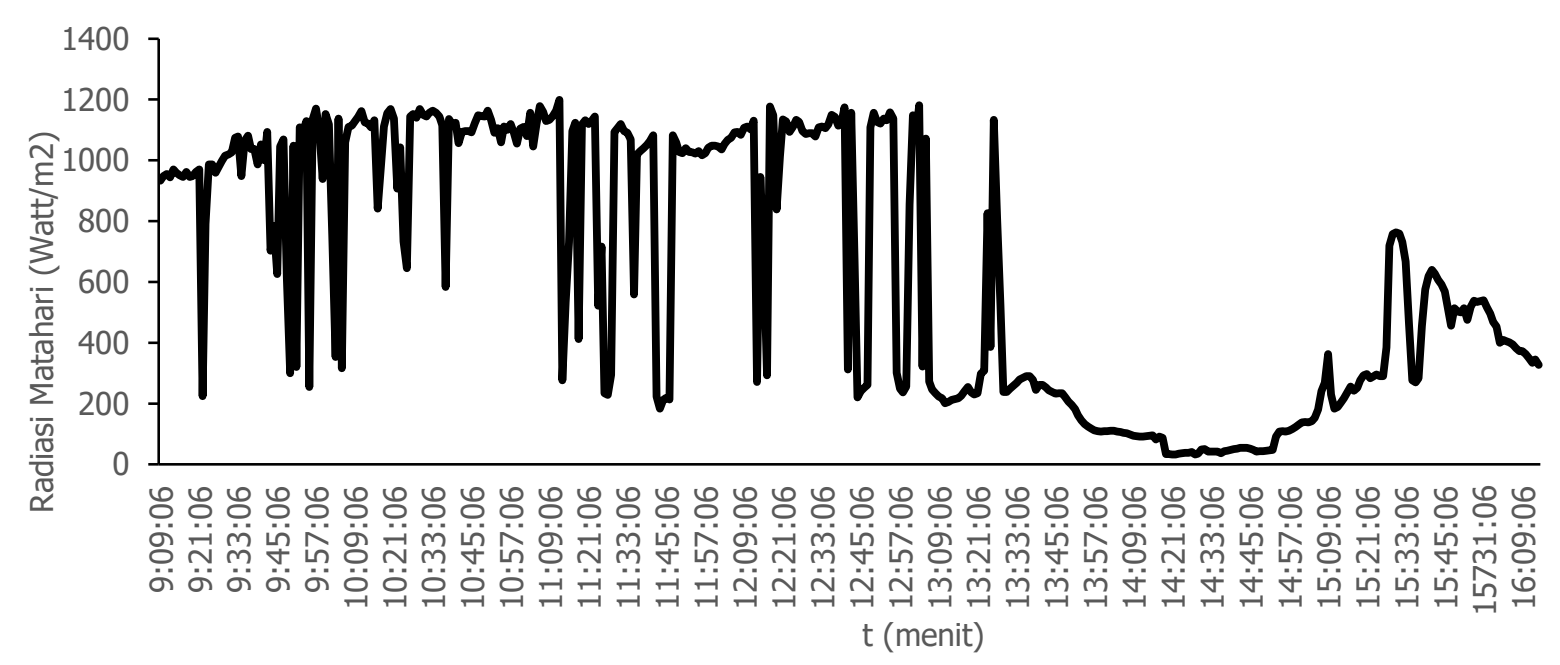

Gambar 8. Kurva radiasi matahari dan waktu (09 Oktober 2013) 


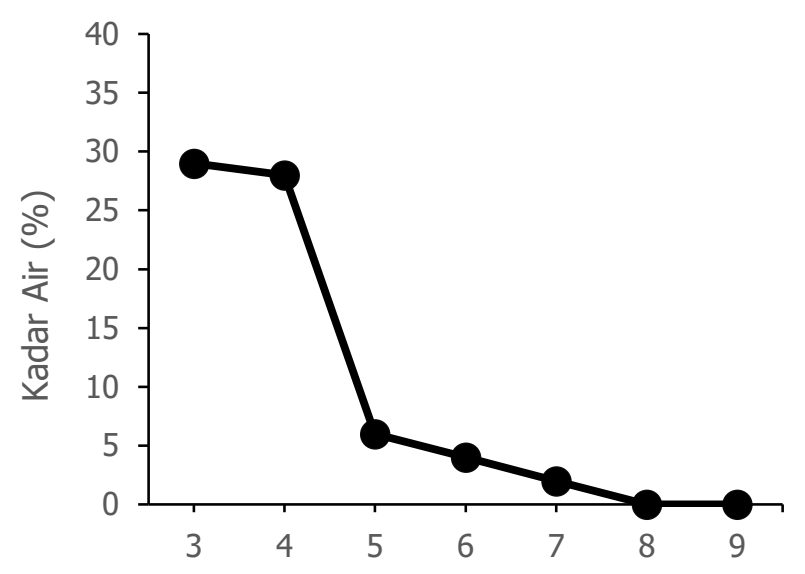

Oktober 2013

Gambar 9. Kurva penurunan kadar air daun gaharu rata-rata (03 s.s. 09 Oktober 2013)

Keseimbangan massa di pelat kolektor berlubang dirumuskan pada Persamaan 3 s.d. 7.

$\dot{m}_{o}=\dot{m}$

$\rho_{o} A_{o} v_{o}=\rho A v$

$\rho_{o}=\rho$

$\rho_{o}\left(\frac{\pi}{4} d_{o}^{2}\right) v_{o} n=\rho\left(\frac{\pi}{4} d^{2}\right) V$

$v_{o}=\left(\frac{d}{d_{o}}\right)^{2}\left(\frac{V}{n}\right)$

Efisiensi kolektor sesaat dihitung berdasarkan selang waktu 15 menit. Persamaan efisiensi kolektor sesaat terlihat pada Persamaan 8 dan 9.

$\bar{\eta}_{k}=\frac{\int_{0}^{15} Q_{u} d t}{\int_{0}^{15} I_{c} A_{c} d t}$

$\bar{\eta}_{k}=\frac{\rho m c_{p}\left(\bar{T}_{o}-\bar{T}_{a}\right) \times 15 \times 60}{\bar{I}_{c} A_{c} \times 15 \times 60}$

Terlihat dari Gambar 10 bahwa radiasi yang diterima oleh permukaan pelat kolektor berkaitan dengan kecepatan udara di atas permukaan kolektor, semakin besar kecepatan udara dalam meter per detik di atas pelat kolektor akan menurunkan radiasi dalam $\mathrm{Watt} / \mathrm{m}^{2}$ yang diserap oleh pelat kolektor sehingga udara panas yang dapat dihisap oleh kipas angin semakin rendah temperaturnya. Temperatur ambien ata-rata adalah 28 ${ }^{\circ} \mathrm{C}$. Efisiensi kolektor sesaat rata-rata yang pelatnya diberi warna hitam akan lebih besar $(\eta=12,83 \%)$ dibandingkan dengan pelat kolektor yang tidak diberi warna hitam $(\eta=$ $6,36 \%$ ). Selain itu, temperatur udara keluar yang tinggi akan menghasilkan efisiensi yang tinggi dan berbeda dengan radiasi yang diterima oleh permukaan yang akan semakin berkurang apabila kecepatan udara semakin besar sehingga efisiensi kolektor juga menurun. Sebagaimana, telah diteliti sebelumnya oleh Badache dkk (2012) untuk model kolektor surya berlubang posisi vertikal dengan dimensi $1,778 \mathrm{~m} \times 0,60 \mathrm{~m} \times 0,15 \mathrm{~m}$. Sebagai pengganti sinar matahari digunakan sebuah lampu. Lampu ini mampu menghasilkan radiasi antara 300 s.d. $700 \mathrm{Watt} / \mathrm{m} 2$. Hasil pengujiannya berupa kurva efisiensi dan laju aliran udara untuk 3 (tiga) jenis pelapisan permukaan kolektor, yaitu tingkat rendah, menengah, dan tinggi yang mampu meningkatkan efisiensi $18 \%$ sampai $90 \%$.

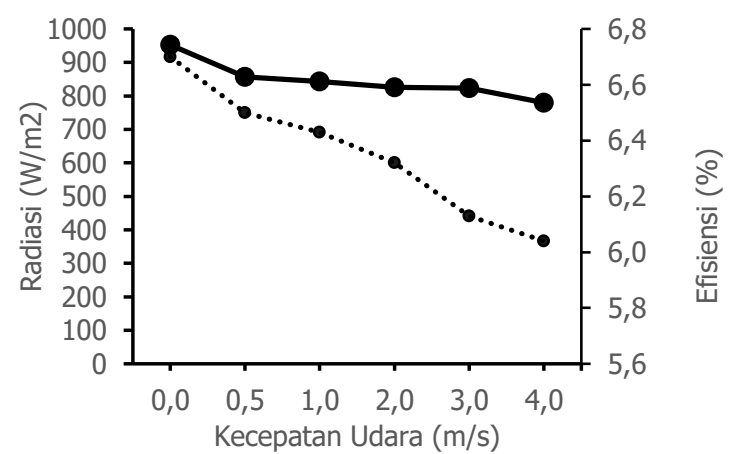

(a) Pelat tanpa warna

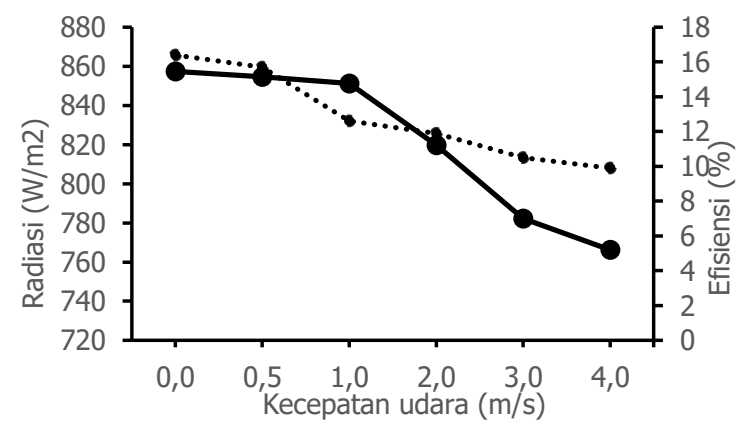

(b) Pelat warna hitam

Gambar 10. Hasil pengujian kolektor surya berlubang di wind tunnel

\section{KESIMPULAN}

Radiasi matahari yang datang ke permukaan kolektor berlubang dipengaruhi oleh cuaca, jika tidak ada hujan dan tidak berawan akan didapat nilai radiasi yang datang ke permukaan tinggi. Kadar air daun gaharu dapat mencapai $10 \%$ selama 2-3 hari ketika radiasi rata-rata yang datang ke permukaan pelat kolektor $\geq 500 \mathrm{~W} / \mathrm{m}^{2}$. Air dalam daun gaharu yang diletakan pada rak bagian bawah lebih cepat dikeluarkan dibandingkan rak yang lainnya dikarenakan udara panas yang dialirkan memiliki temperatur lebih tinggi dibandingkan yang lainnya. Pengujian di wind tunnel menghasilkan efisiensi sesaat kolektor surya berlubang rata-rata $(\eta=12,83 \%)$ untuk pelat kolektor diberi warna hitam dan $((\eta=6,36 \%)$ untuk pelat kolektor yang tidak diberi warna atau sesuai warna pelat alumunium. Kecepatan udara di atas permukaan pelat kolektor juga mempengaruhi efisiensi kolektor surya berlubang. 


\section{UCAPAN TERIMA KASIH}

Ucapan terima kasih disampaikan kepada Kementerian Riset, Teknologi, dan Pendidikan Tinggi Republik Indonesia yang telah mendanai kegiatan penelitian ini.

\section{DAFTAR PUSTAKA}

Arulanandam, S. J., Hollands, K. G. T., \& Brundrett, E. (1999). A CFD heat transfer analysis of the transpired solar collector under no-wind conditions. Solar Energy, 671-3), 93-100. https://doi.org/10.1016/S0038-092X(00)00042-6.

Badache, M., Rousse, D. R., Hallé, S., \& Quesada, G. (2013). Experimental and numerical simulation of a two-dimensional unglazed transpired solar air collector. Solar Energy, 93, 209-219. https://doi.org/10.1016/j.solener.2013.02.036.

Badache, M., Stephane, H., \& Rousse, D. (2012). A full 34 factorial experimental design for efficiency optimization of an unglazed transpired solar collector prototype. Solar Energy, 86(9),

2802-2810. https://doi.org/10.1016/j.solener.2012.06.020.

Bagheri, N., Mohtasebi, S. S., Keyhani, A., Javadikia, P., \& Abbaszadeh, R. (2012). Simulation and control of fan speed in a solar dryer for optimization of energy efficiency. Agricultural Engineering International: CIGR Journal, 14(1), 57-62.

Banout, J., Ehl, P., Havlik, J., Lojka, B., Polesny, Z., \& Verner, V. (2011). Design and performance evaluation of a Double-pass solar drier for drying of red chilli (Capsicum annum L.). Solar Energy, 85(3), 506-515. https://doi.org/10.1016/j.solener.2010.12.017.

Bizzy, I. (1996). Kaji Eksprimental Pemanas Udara Surya Jenis Pelat Berlubang Tanpa Penutup Transparan. Institut Teknologi Bandung.

Bizzy, I., Riman, S., Nukman., Muhammad Z, K., Barlin., \& Hendrie, S. (2012). Kaji eksprimental alat pengering pucuk daun gaharu tenaga surya tipe rak dengan menggunakan pelat berlubang tanpa penutup transparan, 2012.

Collins, M. R., \& Abulkhair, H. (2014). An evaluation of heat transfer and effectiveness for unglazed transpired solar air heaters. Solar Energy, 99, 231-245. https://doi.org/10.1016/j.solener.2013.11.012.

Croitoru, C., Nastase, I., Voicu, I., Meslem, A., \& Sandu, M. (2016). Thermal Evaluation of an Innovative Type of Unglazed Solar Collector for Air Preheating. Energy Procedia, 85(November 2015), 149-155. https://doi.org/10.1016/j.egypro.2015.12.285.

Eryener, D., \& Akhan, H. (2016). The Performance of First Transpired Solar Collector Installation in Turkey. Energy Procedia, 91(1115), 442-449. https://doi.org/10.1016/j.egypro.2016.06.172.

Kamaludin, H. (2012). Uji tingkat keamanan minuman teh gaharu terhadap tikus putih. Laporan hasil penelitian bekerjasama antara Pusat Penlitian Pangan Lembaga Penelitian Universitas Sriwijaya dan Pemerintah Kabupaten Bangka Tengah Provinsi Kepulauan Bangka Belitung.

Li, S., Karava, P., Savory, E., \& Lin, W.E. (2013). Airflow and thermal analysis of flat and corrugated unglazed transpired solar collectors. Solar Energy, 91(2013) 297-315. http://dx.doi.org/10.1016/j.solener.2013.01.028.

Lingayat, A., Chandramohan, V.P., Raju, V.R.K. (2017). Design, development and performance od indirect type solar dryer for banana drying. Energy Procedia, 109(2017), 409-416.

Mohsin, a. S. M., Maruf, M. N. I., Sayem, a. H. M., Mojumdar,
M. R. R., \& Shamim Farhad, H. M. (2011). Prospect \& Future of Solar Dryer: Perspective Bangladesh. International Journal of Engineering and Technology, 3(2), 165-170. https://doi.org/10.7763/IJET.2011.V3.217.

Santoso, B., Rindit, P., HMT, K., Muhammad, S., \& Bizzy, I. (2012). Pemanfaatan daun gaharu menjadi minuman teh yang bersifat fungsional dan pengujian tingkat keamanannya, 2012.

Vijayavenkataraman, S., Iniyan, S., \& Goic, R. (2012). A review of solar drying technologies. Renewable and Sustainable Energy Reviews, 16(5), 2652-2670. https://doi.org/10.1016/j.rser.2012.01.007. 